средвего уха палочками P l a u t-Vin c ent’a. B слысле лечения пока нет спедифической терапии; наиболее благоприятно действуют окислительные препараты. Встречаясь по преимушеству у малокультурных классов населения, заболевание это является социальным недугом, при котором профилактика должна играть первостепенную роль.-Докладчику были заданы вопросы д-ром Ч хон товы ж.

\title{
туберкулезная секиия.
}

Заседание 13/Х.

Т-р М. И. О й феб ах: Организаиионные вопросы строительства проmвотио̆еркулезної организаиии на IV Всесоюзном съезде в Тифлисе.

I-р М. II. 0 й фе еб а х: Новая харантеристика tвс заболевании, принятая IV сьездои.-В прениях приняли участие профф. В о ль те р и Г ор я е в, доц. Г асуль, д-ра М а стба ул, : 3 ах ар ов, Аксянцев, Мясник и др., ұказавпие на некоторые трудности в применении новой классификации tbc. Однако она жизненна, и ее необ́ходимо принять, как обязательную в повседневной работе. Желательно пироко ознакомить врачебные массы с новой характеристикой и создать общий язык между фтизиатрами и интернистами.

Заседание 20/X.

Іоц. Р. Я. Га с уль: Рентеенотерапия tbc, как метод выбора. После жраткого исторического освещения отдельных этапов в развитии рентгенотерапии легочного tbc докладчик остановился на роли лучей в иммуно-биологической борьбе органдзма с вирусом и его продуктами. Рентгеновы лучи вызывают очень сильные очаговые реакцил, которые могут липь сравниться с туберкулиновыми реакциями. Воздействием на клеточные элементы лучи вызывают процесс аутотуберкулинизации. Однако лучи эти не должны уничтожать богатой нужными клеточными элементами грануляционной ткани. Факт наступления очаговых реакций после малых доз (около 5-10\% НЕД) является предостережением, в особенности при экссудативных формах. Нарисовав биологическую картину действия лучей на the, докладчик на основании статистических данных и собственных наблюдений ґва.лифицировал рентгенотерашию, кағ метод выбора.-В дискуссии по докладу

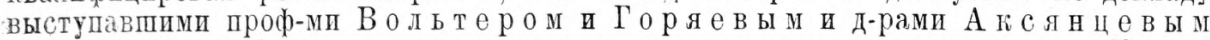
и $\mathrm{K}$ реве ром было указано на интерес постановки данного вопроса в Казани и вместе с тем на необходимость осторожности в рекомендации рентгенотерапии, как лучшего метода лечения $\mathrm{bcc,-этот} \mathrm{лозунг} \mathrm{бросать} \mathrm{в} \mathrm{массы} \mathrm{врачей} \mathrm{еще} \mathrm{рано,}$ он требует большой компетентности терапевта и рентгенолога.

I-р ПI. В. Д е зи де р ь е в: Вопросье питания на IV туберкулезнон соезде.-- Іоклад был дополнен д-рами А к с я н е в ы м и 0 й бо е б а х 0 м. В прениях приняли участие проф. Горя е в и д-р М и рги и.

Заседание $27 / \mathrm{X}$.

І-р М. И. А к с я н ц е в: Bопросьь клиники, рентгена и nатологической анапомии на I' Всесоюзнол туберкулезнол сгезде.-Сообщение вызвало оживленные прения, в которых приняли участие д-ра Г а с уль, Д е з и д е р ь е в, К ревер и М а стбау м, остановившиеся на затронутых докладчиком вопросах. В прениях было высказано пожслание о необходимости, в условиях Казани, договориться рентгенологам до какой-нибудь общей схемы во избежание разнобоя в pá́ote.

Секретарь М. Oйфеогах.

\section{Гигиеническая секция.}

Заседание $6 / \mathrm{XI}$.

I-р П. А. М е х о н о ши и С: Санитарное огследование эсилии сельского населения Звенигпвского и Моркинского кантонов Мариобласти. Весего летом 1928 г. обследовано 447 дворов, из них 361 марийских. Все без исключения обследованные избы имеют деревянные срубные стены, деревянные пол и потолок и в громадном большинстве $(89,7 \%)$ тесовые крыши; толщина стен в $67,2 \%$ превышает 23 сант., фундамент у изб отмечен всего лишь в 3 случаях. Точно также редזо встречаются форточки---в $3,4^{\circ} \%$, двойные рамы-в $18,6^{0} \%$, голландские печи в $1,3 \%$, отуожие места-в 2,3\%. Средние размеры изб: объем без печи-57,9 куб́. метр., площадь избы-24,8 кв. метр., высота комнат-2,39 метр. На человека в среднем приходится 4,64 кв. метр. всей площади пола и 1,63 кв. метр. жилых жомнат. Жіллиные условия у зажиточных крестьян значительно лучпе, чем у середняков и особенно у бедняков. Нз бытовых особенностей отмечены: кровати имеютея в $63,5^{\circ} \%$ всех изб, полати-в 8, $3 \%$, рукомойники-в 34,6\%, лампы- 
в $97,7 \%$, бани-в $77,4 \%$, в том числе в 4,3\% по белому. В 6 избах обнаружена печь с топкой по черному, без трубы. Ломашние животные в избах содержатся в $25,7 \%$, причем в $19,2 \%$ в избу заводят көрмить и доить коров. Клошы отмечень в $65,5 \%$, тараканы-в $68,5 \%$. В $53,9 \%$ кроме кухни имеются жилые комнаты. Средний состав семьи у крестьян мари-5,3 чел, По докладу высказались д.ра Іось, Логачев, Ал егсандров, Князевский, Сигалевич, Менде ль с с н и проф. М ил о с ла В С ки й. Секретарь JI. Jось.

\section{Общегородская конференция при Самарской научной ассоциация врачей,}

Заседание $10 / \mathrm{X}$.

Д-р С. И. Г а ль п е р и н сделал доклад о оилируоинями у беременных, ролсенич и родильнии. Реакция определенйя билирубина в крови была проделана на материале III Самарской акушерско-гинекологической больницы. Всего было. исследовано 300 женщин, из которых в первой половине беременности 40, давших в среднем 3,6 мгр. билирубина, во второй-56, давпих среднюю цифру в 4,7 мгр., во время родов-90, давпих среднюю цифру в 4,86 мгр., и в послеродовом периоде -114, у которых средняя цифра содержания билирубина в крови оказалась равною 5,2 мгр. Докладчик придерживается взгляда пाколы A s c h off'a o внепеченочном происхождении билирубина и приходит к след. выводам: 1) определение билирубина в крови диагностической реакцией на раннюю беременность служить не может; 2) во второй половине беременности билирубин определяется у всех беременных; 3) повыпенная билирубинэмия наряду с общей клинической картиной может служить признаком надвигающегося токсикоза беременных; 4) повыпенная билирубинэмия есть доказательство гиперфункции всего реактивного аппаратс и в частности ретикуло-эндотелиальной системы.-Прения: проф. К а в е ц $\mathrm{k}$ й. Д-ра В ал и ц к и й, В о ль с к и й и В ы р ып а е в.

Заседание $17 / \mathrm{X}$.

П-р С оски нд сделал отчетный доклад о Всесоюзном сәзде nо борьо̃е $c t b c$.

Заседание $31 / \mathrm{X}$.

I-р С те рн о в: Omiеm о научной коландировке на курсы по рентгенологии.

Д-ра ІІІ и л и н и Л юб о м у д р о в: Peнmгенотерапия трахомы. Быстрые успехи последнего времени в области рентгенотехники и рентгенобиологии дали возможность применить рентгенотерапию и при заболеваниях органа зрения, главным образом при трахоме. Целый ряд авторов установил, что хрусталик, стекловидное тело и сетчатка не повреждаются даже больпими дозами рентеновских лучей. Лимфоидная ткань легче всего подвергается действию последних, за ней следует соединительная ткань. Это-то обстоятельство и лежит в основе успешного действия х-лучей при трахоме. Всего докладчиками был подвергнут рентгенотерапии 21 трахоматозный больной, но из них полностью был проведен гурс лечения только у 15 . Из этих 15 больных полное излечение было достигнуто у 9, у остальных же наступило значительное улучшение. Лечение оказалось совершенно безболезненным и, как правило, лишь с небольшими реактивными явлениями, исчезающими в несколько дней. Легче всего поддется лечению трахома в I стадии, затем-трахома II стадии и труднее всего-трахома III стадии. При этом рассасываются полностью не только лимфоидные элементы, но и соединитедьнотканные. В виду несомненного успеха рентгенотерашии трахомы докладчики надеются, что этот способ лечения наиболее распространенного и тяжелого заболевания глаза выйдет из области эксперимента на более пирокий путь массового .ечения, преимущественно случаев свежей зернистой трахомы.-В обмене мнений по докладу приняли участие врачи Ио фо ан и Соскинд. Секретарь Вольский. 